\title{
39. Sr-ISOTOPE AND RARE-EARTH ELEMENT GEOCHEMISTRY OF DSDP LEG 37 BASALTS
}

\author{
R.K. O'Nions and R.J. Pankhurst, \\ Department of Geology and Mineralogy, Parks Road, Oxford, U.K.
}

\section{ANALYTICAL METHODS}

\section{Strontium Isotopes}

Only the freshest samples were selected for study. Each sample leached with $6 \mathrm{M} \mathrm{HCl}$ before total dissolution in order to remove contaminant $\mathrm{Sr}$ derived from seawater. Samples were disolved in a $\mathrm{HF}-\mathrm{HNO}_{3}$ mixture and $\mathrm{Sr}$ was extracted by conventional cation exchange techniques (Pankhurst and O'Nions, 1973). Isotopic analyses were performed on a VG Micromass 30 using techniques similar to those described previously (O'Nions and Pankhurst, 1973).

\section{Rare-Earth Elements}

Rare-earth element abundances were determined by mass spectrometric isotope dilution. A mixed-solvent anion exchange procedure (Hooker et al., in press) was employed for the separation of the REE and isotopic analyses were performed on the Oxford 12 " mass spectrometer.

\section{RESULTS}

\section{Strontium Isotopes}

${ }^{87} \mathrm{Sr} /{ }^{86} \mathrm{Sr}$ ratios are presented in Table 1 . The samples analyzed cover a range in major element chemistry. For example, $\mathrm{TiO}_{2}$ contents range from $0.62 \%$ to $1.14 \%$. The measured ${ }^{87} \mathrm{Sr} /{ }^{86} \mathrm{Sr}$ ratios for the samples from Hole 332A, however, are indistinguishable and average 0.70296 . The five samples analyzed from Hole 332B represent most of the major element variation seen in Leg 37 basalts and have ${ }^{87} \mathrm{Sr} /{ }^{86} \mathrm{Sr}$ ratios ranging from $0.70287 \pm 4$ to $0.70308 \pm 4$. This range is a little outside analytical error, but the average value for the five samples is 0.70298 . The sample analyzed from Hole $333 \mathrm{~A}$ has an ${ }^{87} \mathrm{Sr} /{ }^{86} \mathrm{Sr}$ ratio of $0.70304 \pm 4$ and is indistinguishable from the mean values determined for Holes 332A and 332B. The one sample analyzed from Site 335 yielded an ${ }^{87} \mathrm{Sr} /{ }^{86} \mathrm{Sr}$ of $0.70316 \pm 4$ and is the highest value determined for a Leg 37 basalt in this study. It is not clear at present whether or not the slightly higher ${ }^{87} \mathrm{Sr} /{ }^{86} \mathrm{Sr}$ ratios observed in this sample and some of those from Hole 332B are simply due to alteration not completely removed by the leaching technique.

\section{Rare-Earth Elements}

The abundances of nine rare-earth elements (Table 2) have been determined in four Leg 37 samples. Three of these samples are from Hole 332B and one is from Site 335. The chondrite normalized REE distribution patterns range from slightly light REE enriched (Site 355 sample) to light REE depleted (Figure 1). $\mathrm{Ce}_{\mathrm{N}} / \mathrm{Yb}_{\mathrm{N}}$ ratios range from 1.30 to 0.58 and are compared with $\mathrm{TiO}_{2}$ and $\mathrm{Sr}$ contents and ${ }^{87} \mathrm{Sr} /{ }^{86} \mathrm{Sr}$ ratios in Table 3.

\section{DISCUSSION}

The presumed magmatic ${ }^{87} \mathrm{Sr} /{ }^{86} \mathrm{Sr}$ ratios of these rocks of $0.70295-70300$ is comparable to those obtained for Mid-Atlantic Ridge basalts from the southern section of the Reykjanes Ridge (O'Nions and Pankhurst, 1974) and from part of the Kolbeinsey Ridge north of Iceland (Pankhurst and O'Nions, unpublished). It appears to indicate a uniformity in the $\mathrm{Rb}-\mathrm{Sr}$ evolution of ocean floor basalts (and the mantle source region from which they are derived) over a large portion of the northern Atlantic Ocean. It is significant, however, that other sections of the Mid-Atlantic Ridge show considerably lower ${ }^{87} \mathrm{Sr} /{ }^{86} \mathrm{Sr}$ ratios, down to 0.7023 (Hart, 1976).

The REE abundances (with the possible exception of Sample 332B-10-3, \#2A) are similar to those reported for Mid-Ocean Ridge basalts (e.g., Kay et al., 1970; O'Nions and Pankhurst, in press; Schilling 1973, 1975). Unlike the Reykjanes Ridge and Iceland (O'Nions and Pankhurst, in press) the Leg 37 basalts do not show a correlation between $\mathrm{Ce}_{\mathrm{N}} / \mathrm{Yb}_{\mathrm{N}}$ and ${ }^{87} \mathrm{Sr} /{ }^{86} \mathrm{Sr}$. Further the spread of $\mathrm{Ce}_{\mathrm{N}} / \mathrm{Yb}_{\mathrm{N}}$ values within Hole 332B alone from $\sim 0.6$ to $\sim 1.3$ is not consistent with what might be expected from Schilling's (1975) plume model for the Azores, since this range corresponds to a considerable portion of the variation which Schilling ascribes to the mixing of two end members.

In conclusion the $\mathrm{Sr}$-isotope geochemistry carried out to date is compatible with all samples being derived from a mantle which is essentially homogeneous isotopically. It is unlikely that the range of $\mathrm{Ce}_{N} / \mathrm{Yb}_{\mathbb{N}}$ ratios could be solely due to differential partial melting of a source which is homogeneous with respect to these elements. Some minor heterogenity in REE distribution or low-pressure crystal fractionation may be responsible.

\section{REFERENCES}

Hart, S.R., 1976. LIL-element geochemistry, Leg 34 basalts. In Hart, S.R., Yeats, S.R., et al., Initial Reports of the Deep Sea Drilling Project, Volume 34: Washington (U.S. Government Printing Office), p. 283-288.

Hooker, P., O'Nions, R.K., and Pankhurst, R.J., in press. Determination of rare-earth elements in USGS standard rocks by mixed-solvent ion exchange and massspectrometric isotope dilution: Chem. Geol. 
TABLE 1

Sr-Isotope Data ${ }^{a}$

\begin{tabular}{llllll}
\hline Hole 332A & & & & \\
Sample & $8-2, \# 23$ & $12-1, \# 9$ & $17-1, \# 6$ & $29-1, \# 9$ & \\
${ }^{87} \mathrm{Sr} /{ }^{86} \mathrm{Sr}$ & $0.70302 \pm 4$ & $0.70296 \pm 4$ & $0.70300 \pm 4$ & $0.70295 \pm 6$ & \\
& & & & $0.70299 \pm 4$ & \\
Hole 332B & & & & & \\
Sample & $10-3, \# 2 \mathrm{~A}$ & $16-2, \# 8$ & $25-1, \# 16$ & $35-3, \# 4$ & $37-3, \# 6$ \\
${ }^{87} \mathrm{Sr} /{ }^{86} \mathrm{Sr}$ & $0.70296 \pm 7$ & $0.70292 \pm 4$ & $0.70287 \pm 4$ & $0.70308 \pm 4$ & $0.70295 \pm 4$ \\
& & & & \\
$\mathrm{Hole} 333 \mathrm{~A}$ & $0.70303 \pm 8$ & & & & \\
Sample & $11-1, \# 12$ & & & & \\
${ }^{87} \mathrm{Sr} /{ }^{86} \mathrm{Sr}$ & $0.70304 \pm 4$ & & & & \\
Site 335 & & & & & \\
Sample & $14-4, \# 10$ & & & & \\
${ }^{87} \mathrm{Sr} /{ }^{86} \mathrm{Sr}$ & $0.70316 \pm 4$ & & & & \\
\hline
\end{tabular}

${ }^{\text {a }}$ All data relative to 0.70800 for Eimer and $\mathrm{Amend}^{\mathrm{SrCO}_{3}}$ standard.

TABLE 2

Rare-Earth Element Concentrations

\begin{tabular}{lrrrrrrrrr}
\hline & $\mathrm{La}$ & $\mathrm{Ce}$ & $\mathrm{Nd}$ & $\mathrm{Sm}$ & $\mathrm{Eu}$ & $\mathrm{Gd}$ & $\mathrm{Dy}$ & $\mathrm{Er}$ & $\mathrm{Yb}$ \\
\hline Hole 332B & & & & & & & & & \\
$10-3, \# 2 \mathrm{~A}$ & - & 12.00 & 8.33 & 2.45 & 0.91 & 3.12 & 3.88 & 2.36 & 2.36 \\
$25-1, \# 16$ & - & 6.41 & 5.00 & 1.71 & 0.70 & 2.52 & 3.19 & 2.10 & 2.04 \\
$35-3, \# 4$ & - & 4.59 & 3.44 & 1.18 & 0.50 & 1.81 & 2.34 & 1.59 & 1.61 \\
Site 335 & & & & & & & & \\
$14-4, \# 10$ & - & 6.52 & 6.22 & 2.37 & 0.91 & 3.57 & 4.38 & 2.94 & 2.87 \\
\hline Note: = not determined. & & & & & & &
\end{tabular}

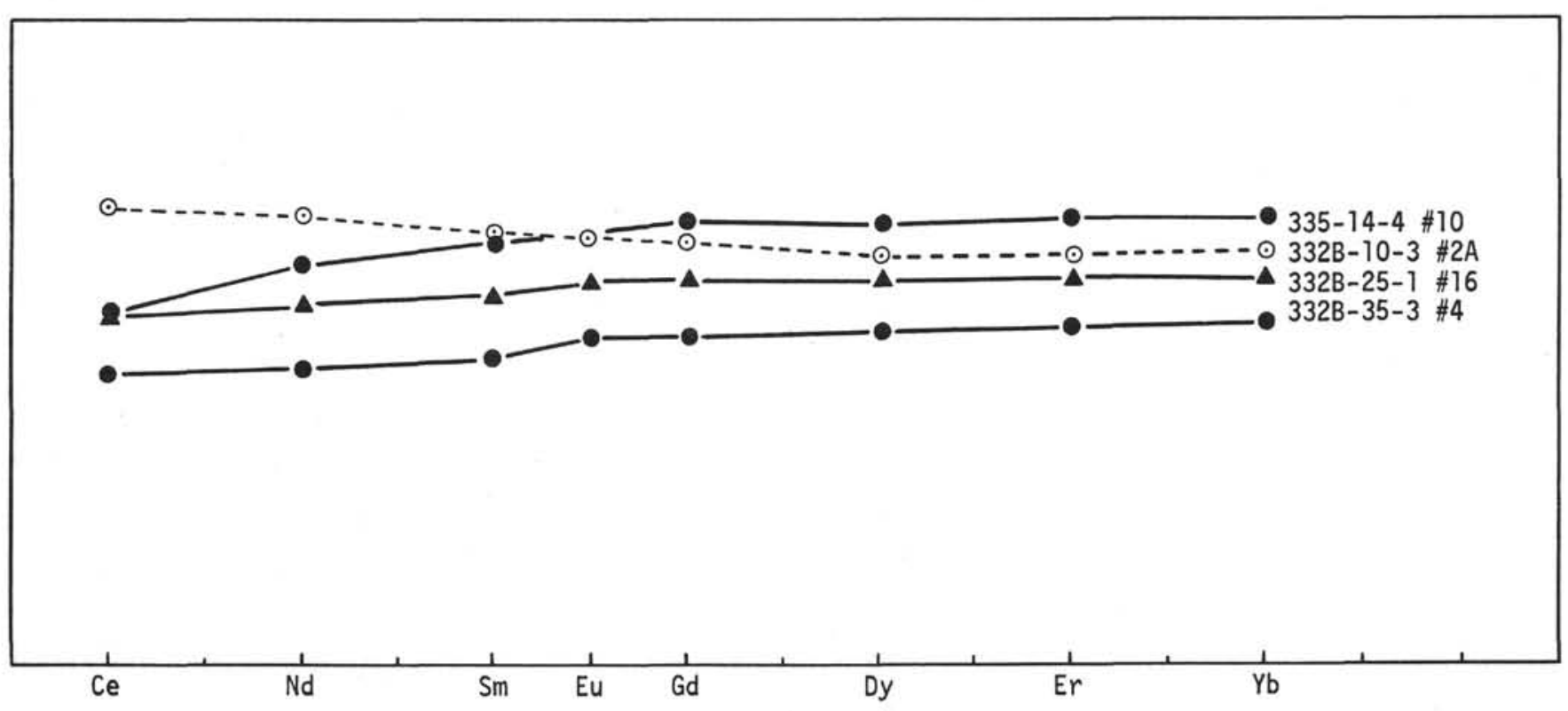

Figure 1. Chondrite normalized REE distribution patterns for Leg 37 basalts.

Kay, R., Hubbard, N.J., and Gast, P.W., 1970. Chemical characteristics and origin of oceanic ridge volcanic rocks: J. Geophys. Res., v. 75, p. 1585-1614.
O'Nions, R.K. and Pankhurst, R.J., 1973. Secular variations in the $\mathrm{Sr}$-isotope composition of Icelandic volcanic rocks: Earth Planet. Sci. Lett., v. 21, p. 13-21. 
TABLE 3

$\mathrm{Ce}_{\mathrm{N}} / \mathrm{Yb}_{\mathrm{N}}$ Ratios Compared with ${ }^{87} \mathrm{Sr} /{ }^{86} \mathrm{Sr}, \mathrm{TiO}_{2}$, and $\mathrm{Sr}$

\begin{tabular}{lcccr}
\multicolumn{1}{c}{ Sample } & $\mathrm{Ce}_{\mathrm{N}} / \mathrm{Yb}_{\mathrm{N}}$ & ${ }^{87} \mathrm{Sr} /{ }^{86} \mathrm{Sr}$ & $\mathrm{TiO}_{2}(\mathrm{wt} \%)$ & $\mathrm{Sr}(\mathrm{ppm})$ \\
\hline Hole 332B & & & & \\
$10-3, \# 2 \mathrm{~A}$ & 1.30 & $0.70300 \pm 7$ & 1.05 & 112 \\
25-1, \#16 & 0.80 & $0.70287 \pm 4$ & 0.82 & 87 \\
$35-3, \# 4$ & 0.72 & $0.70308 \pm 4$ & 1.12 & 100 \\
Site 335 & & & & \\
$14-4, \# 10$ & 0.58 & $0.70316 \pm 4$ & 1.04 & - \\
\hline
\end{tabular}

Note: $=$ not determined.
1974. Petrogenetic significance of isotope and trace element variations in volcanic rocks from the MidAtlantic: J. Petrol., v. 15, p. 603-34.

in press. Nature and development of magma sources beneath Iceland and the Reykjanes Ridge: J. Petrol.

Pankhurst, R.J. and O'Nions, R.K., 1973. Determination of $\mathrm{Rb} / \mathrm{Sr}$ and ${ }^{87} \mathrm{Sr} /{ }^{86} \mathrm{Sr}$ ratios of some standard rocks and evaluation of X-ray fluorescence spectrometry in $\mathrm{Rb}-\mathrm{Sr}$ geochemistry: Chem. Geol., v. 12, p. 127-36.

Schilling, J.G., 1973. Iceland mantle plume: Geochemical study of the Reykjanes Ridge: Nature, v. 242, p. 565.

1975. Azores mantle blob: rare-earth evidence: Earth Planet. Sci. Lett., v. 25, p. 103-116. 